\title{
Hubungan Antara Status Gizi dan Pola Makan dengan Kejadian Anemia Pada Remaja Putri
}

\author{
Anis Muhayati ${ }^{1}$, Diah Ratnawati ${ }^{2}$ \\ ${ }^{1,2}$ Fakultas Ilmu Kesehatan, Universitas Pembangunan Nasional Veteran Jakarta \\ Jalan Limo Raya Kelurahan Limo Kecamatan Limo Kota Depok Kode Pos 16515 \\ E-mail: ratnawatidiah@yahoo.co.id
}

\begin{abstract}
Abstrak
Anemia merupakan salah satu masalah gizi pada remaja putri. Anemia adalah suatu keadaan ketika kadar hemoglobin dalam darah kurang dari nilai normal $(<12 \mathrm{gr} / \mathrm{dl})$ pada wanita yang ditandai dengan gejala klinis, yaitu lesu, lemah, pusing, mata berkunang-kunang, dan wajah pucat. Penelitian ini bertujuan untuk mengetahui hubungan status gizi dan pola makan dengan kejadian anemia pada remaja putri di SMA Negeri 97 Jakarta. Desain penelitian ini adalah kuantitatif dengan pendekatan cross sectional. Subyek penelitian ini sebanyak 188 remaja putri dipilih secara stratified random sampling. Analisis bivariat menggunakan uji chi-square dengan tingkat kepercayaan $95 \%$. Hasil penelitian menunjukkan ada hubungan bermakna antara status gizi dengan kejadian anemia pada remaja putri dengan nilai $\mathrm{p}=0,008(<0,05)$. Analisis pola makan dengan kejadian anemia pada remaja yang berarti ada hubungan antara pola makan dengan kejadian anemia dengan $\mathrm{p}=0,004(<0,05)$ dan $\mathrm{OR}=0,407$. Remaja putri di SMA Negeri 97 Jakarta hendaknya lebih memperhatikan pola makan dan status gizi sehingga dapat mencegah terjadinya anemia pada remaja yang mengganggu proses belajar dan aktivitas remaja.
\end{abstract}

Kata kunci $\quad$ : Kejadian Anemia, Pola Makan, Remaja Putri, Status Gizi.

\begin{abstract}
Anemia is one of the nutritional problems for adolescent girls. Anemia is a condition when blood hemoglobin levels are less than normal $(<12 \mathrm{gr} / \mathrm{dl})$ in women characterized by clinical symptoms: lethargy, weakness, dizziness, blurred eyes, and pale faces. This study aims to determine the correlation between nutritional status, diet, and anemia phenomenon in adolescent girls in SMA Negeri 97 Jakarta. The design of this research is quantitative with cross sectional approach. The subjects of this study are 188 adolescent girls selected stratified random sampling. Bivariate analysis using chi-square test with $95 \%$ confidence level. The result of pearson chisquare test showed that there was a significant correlation between nutritional status and anemia phenomenon in adolescent girls with $p$ value $=0,008(<0,05)$. Analysis of diet with anemia phenomenon in adolescent which means there is correlation between diet with anemia with $p$ value $=0,004(<0,05)$ and $0 R=0,407$. Adolescent girls in SMA Negeri 97 Jakarta should pay more attention to diet and nutritional status to prevent the anemia phenomenon that may interfere the learning process and activity of teenagers.
\end{abstract}

Keywords : : Anemia, Diet, Nutrition Status, Adolescent Girls. 


\section{Pendahuluan}

Anemia adalah suatu keadaan dimana jumlah sel darah merah atau kadar hemoglobin (Hb) di dalam darah lebih rendah daripada nilai normal untuk kelompok orang menurut umur dan jenis kelamin. Pada orang sehat butir-butir darah merah mengandung hemoglobin, yaitu sel darah merah yang bertugas untuk membawa oksigen serta zat gizi lain seperti vitamin dan mineral ke otak dan ke jaringan tubuh. Kadar $\mathrm{Hb}$ normal pada laki-laki dan perempuan terdapat perbedaan. Kadar $\mathrm{Hb}$ untuk pria anemia yaitu kurang dari 13,5 g/dl, sedangkan kadar $\mathrm{Hb}$ pada wanita kurang dari $12 \mathrm{~g} / \mathrm{dl} .{ }^{1,2}$ Anemia dapat menimbulkan beberapa gejala klinis.

Gejala klinis anemia dapat berupa lesu, lemah, pusing, mata berkunang-kunang, dan wajah pucat. Faktor yang dapat menyebabkan anemia adalah perdarahan hebat, kurangnya zat besi dalam tubuh, kekurangan asam folat, kekurangan vitamin $\mathrm{B} 12$ dan $\mathrm{C}$, penyakit malaria, infeksi cacing, leukemia, penyakit kronis, status gizi, lamanya menstruasi, tingkat pendidikan orang tua, tingkat pengetahuan, dan tingkat ekonomi. ${ }^{2,3}$

Anemia merupakan masalah gizi di dunia. Berdasarkan laporan World Health Organization/WHO menyatakan bahwa lebih dari $30 \%$ atau 2 milyar orang di dunia berstatus anemia. ${ }^{4}$ Prevalensi anemia di Indonesia, yaitu $21,7 \%$ dengan penderita anemia berumur 5-14 tahun sebesar $26,4 \%$ dan $57 \%$ berumur $15-24$ tahun. ${ }^{5}$ Data tersebut menunjukkan bahwa anemia merupakan masalah gizi yang sering dialami oleh remaja.

Remaja merupakan transisi dari masa kanak-kanak ke masa dewasa yang ditandai dengan sejumlah perubahan biologis, kognitif, dan emosional. Oleh karena itu, masa remaja adalah masa yang lebih banyak membutuhkan energi dan membutuhkan nutrisi dua kali lipat pada masa pertumbuhan daripada tahun-tahun yang lain. ${ }^{1,6}$ Usia remaja dibagi menjadi dua periode, yaitu periode masa puber pada usia 1218 tahun yang terdiri atas masa prapubertas, masa pubertas usia 14-16 tahun, dan masa akhir pubertas usia 17-18 tahun dan periode remaja adoleses pada usia 19-21 tahun. ${ }^{2}$ Menurut data Riskesdas, prevalensi anemia defisiensi besi banyak ditemukan pada remaja perempuan sebesar $22.7 \%$, sedangkan anemia defisiensi besi pada remaja laki-laki sebesar $12.4 \%{ }^{7}$

Remaja putri lebih beresiko menderita anemia daripada remaja putra setiap bulannya mengalami menstruasi, sering kali menjaga penampilan, ingin mendapatkan tubuh ideal sehingga berdiet dan mengurangi makan. Pola menstruasi yang tidak normal dapat menyebabkan anemia karena terjadi pengeluaran darah yang berlebih, sehingga hemoglobin yang terkandung dalam darah juga ikut terbuang. ${ }^{8,9}$ Hal tersebut dibuktikan dari penelitian di MTs Ma'Arif Nyatnyono Kabupaten Semarang $(p=0,002)$ menyatakan bahwa responden yang mempunyai pola menstruasi tidak baik cenderung 5,7 kali lebih besar mengalami anemia dibandingkan responden yang mempunyai pola menstruasi baik. Remaja putri biasanya sangat memperhatikan bentuk tubuh sehingga sering melakukan diet untuk memperoleh bentuk tubuh yang ideal. ${ }^{10}$

Diet yang seimbang menghasilkan kecukupan asupan zat gizi tetapi remaja putri sering berdiet dengan cara yang kurang benar seperti melakukan pantangan-pantangan, mengurangi frekuensi dan membatasi makan untuk mencegah kegemukan sehingga menyebabkan gangguan pertumbuhan dan kekurangan zat gizi yang dibutuhkan tubuh termasuk zat besi.,11 Zat besi merupakan komponen penting hemoglobin. Penelitian pada remaja putri di Bekasi didapatkan data bahwa status gizi berkorelasi positif dengan konsentrasi hemoglobin, artinya semakin buruk status gizi seseorang maka semakin rendah kadar Hb didalam darah. ${ }^{12}$

Status gizi remaja yang kurang maupun berlebih merupakan masalah gizi remaja yang di karenakan perilaku konsumsi makanan yang salah, yaitu keseimbangan antara konsumsi nutrisi dengan kecukupan nutrisi yang dianjurkan. Status gizi kurang terjadi apabila tubuh kekurangan zat-zat gizi esensial dan sebaliknya jika tubuh kelebihan zat gizi maka remaja akan menderita gizi lebih dan obesitas. ${ }^{13}$ Selain itu, meningkatnya aktivitas sekolah maupun berbagai aktivitas organisasi dan ekstrakurikuler yang tinggi pada remaja akan mempengaruhi kebiasaan makannya. 
Kebiasaan makan yang ideal, yaitu frekuensi makan tiga kali sehari dengan rentang waktu makan yang hampir sama dalam sehari, dan ditambah dua makanan ringan porsi kecil yang menyehatkan. ${ }^{14}$ Pola konsumsi makanan yang sering tidak teratur, sering jajan, sering tidak sarapan, dan sama sekali tidak makan siang. Kondisi tersebut, ditambah juga dengan kebiasaan mengkonsumsi minuman yang menghambat absorbsi zat besi akan mempengaruhi kadar hemoglobin.

Remaja dengan aktivitas sosial yang tinggi akan memperlihatkan peran teman sebaya seperti berkumpul untuk makan di rumah makan yang menyajikan siap saji atau fast food yang pada umumnya mengandung lemak dan kalori yang dapat menyebabkan kegemukan dan menjadi faktor pemicu timbulnya penyakit lain. ${ }^{15}$ Penelitian di MTs Ma'Arif Nyatnyono Kabupaten Semarang juda diperoleh hasil bahwa remaja putri yang mempunyai pola makan tidak baik cenderung 5,4 kali lebih besar mengalami anemia daripada remaja putri yang mempunyai pola makan baik. Anemia pada remaja putri yang tidak ditangani dengan baik akan memiliki dampak yang berbahaya. ${ }^{10}$

Masalah gizi pada remaja merupakan hal yang perlu diatasi dengan serius, namun remaja masih menjadi kelompok yang terabaikan. Program pemerintah baru ditunjukkan pada ibu hamil agar tidak melahirkan anak yang anemia, padahal remaja yang menderita anemia akan berdampak lanjut dan meningkatkan resiko perdarahan pada saat persalinan yang menyebabkan kematian ibu. Hal tersebut terbukti program Dinas Kesehatan, yaitu Program Kesehatan Peduli Remaja (PKPR) masih terbatas menangani masalah nutrisi pada remaja dan belum efektif di semua Puskesmas Indonesia. Masalah ini memerlukan perhatian dari semua tenaga kesehatan termasuk perawat. Oleh karena itu, penelitian ini dilakukan untuk mengetahui hubungan status gizi dan pola makan dengan kejadian anemia pada remaja putri di SMA Negeri 97 Jakarta.
Hasil

Tabel 1. Distribusi Frekuensi Berdasarkan Status Gizi, Pola Makan, dan Kejadian Anemia Pada Remaja Putri di SMA Negeri 97 Jakarta Tahun $2018 \quad(\mathrm{n}=188)$

\begin{tabular}{ccc}
\hline Status Gizi & Frekuensi & Presentase(\%) \\
\hline IMT Kurang & 62 & 33 \\
IMT Normal & 106 & 56,4 \\
IMT Berlebih & 20 & 10,6 \\
\hline Pola Makan & Frekuensi & Presentase(\%) \\
\hline Teratur & 89 & 47,3 \\
Tidak teratur & 99 & 52,7 \\
\hline Kejadian & Frekuensi & Presentase(\%) \\
Anemia & & \\
\hline Anemia & 100 & 53,2 \\
Tidak anemia & 88 & 46,8 \\
\hline
\end{tabular}

Tabel 1 diatas menunjukkan bahwa sebanyak 62 responden (33\%) memiliki status gizi dengan IMT kurus, 106 responden $(56,4 \%)$ IMT normal, dan kategori IMT berlebih, yaitu sebanyak 20 responden $(10,6 \%)$. Status gizi merupakan kondisi tubuh responden yang dilihat dari makanan yang dikonsumsi dan penggunaan zat gizi. Nilai IMT merupakan salah satu alat ukur yang dapat digunakan untuk memantau status gizi.

Dari hasil data pola makan, maka didapatkan data bahwa hamper sebagian besar atau $52,7 \%$ pasien tidak makan dengan pola makan tidak teratur yaitu dengan jumlahh frekuensi sebenya 99 respoden, begitupun sebaliknya dimana pasien yang melaksakaan pola makan yang teratur hanya sebanyak 89 orang dengan presentase adalah $47,3 \%$.

Dari hasil distribusi anemia maka didapatkan hasil bahwa sekitar 100 orang dari 188 orang yang diteliti mengalami anemia dengan presentase sebesar $53,2 \%$ dan sisanya sekitar $46,8 \%$ tidak mengalami anemia atau dengan besaran jumlah responden sebanyak 88 orang. 
Tabel 2. Analisis Hubungan Status Gizi dengan Kejadian Anemia pada Remaja Putri di SMA Negeri 97 Jakarta $(\mathrm{n}=188)$

\begin{tabular}{ccccc}
\hline \multirow{2}{*}{ Status Gizi } & \multicolumn{2}{c}{ Kejadian Anemia } & Total & P Value \\
& Anemia & $\begin{array}{c}\text { Tidak } \\
\text { Anemia }\end{array}$ & & \\
\hline IMT Kurang & $42(67,7 \%)$ & $20(32,3 \%)$ & $62(100 \%)$ & 0,008 \\
IMT Normal & $46(43,4 \%)$ & $60(56,6 \%)$ & $106(100 \%)$ & \\
IMT Berlebih & $12(60 \%)$ & $8(40 \%)$ & $20(100 \%)$ & \\
\hline Total & $100(53.2 \%)$ & $88(46.8 \%)$ & $188(100 \%)$ & \\
\hline
\end{tabular}

Tabel 2 menunjukkan bahwa 42 responden $(67,7 \%)$ memiliki IMT kurus dan mengalami anemia sedangkan 20 responden $(32,3 \%)$ tidak mengalami anemia. Remaja dengan IMT Normal yang mengalami anemia sebanyak 46 responden

$(43,4 \%)$ dan 60 responden $(56,6 \%)$ tidak mengalami anemia. Remaja dengan IMT
Berlebih yang mengalami anemia sebanyak 12 responden $(60 \%)$ dan 8 responden $(40 \%)$ tidak mengalami anemia. Hasil analisa data dengan uji Pearson Chi-Square diperoleh nilai $\mathrm{p}=0,008$ ( $p$ value $<0,05$ ) sehingga dapat disimpulkan ada hubungan antara status gizi dengan kejadian anemia.

Tabel 3. Analisa Hubungan Pola Makan dengan Kejadian Anemia pada Remaja Putri di SMA Negeri 97 Jakarta $(\mathrm{n}=188)$

\begin{tabular}{cccccc}
\hline \multirow{2}{*}{ Pola Makan } & \multicolumn{2}{c}{ Kejadian Anemia } & Total & P Value & OR \\
& Anemia & $\begin{array}{c}\text { Tidak } \\
\text { Anemia }\end{array}$ & & \\
\cline { 1 - 4 } Teratur & $37(41,6 \%)$ & $52(58,4 \%)$ & $89(100 \%)$ & \multirow{2}{*}{0,004} & 0,407 \\
Tidak Teratur & $63(63,6 \%)$ & $36(36,4 \%)$ & $99(100 \%)$ & & \\
\cline { 1 - 4 } Total & $100(53,2 \%)$ & $88(46,8 \%)$ & $188(100 \%)$ & & \\
\hline
\end{tabular}

Tabel 3 menunjukkan bahwa 37 responden $(41,6 \%)$ memiliki pola makan teratur dan berstatus anemia, 52 responden $(58,4 \%)$ tidak mengalami anemia. Remaja dengan pola makan tidak teratur yang mengalami anemia sebanyak 63 responden $(63,6 \%)$ dan 36 responden $(36,4 \%)$ tidak mengalami anemia. Dari hasil uji Continuity Correction diperoleh nilai $\mathrm{p}=0,004$ ( $\mathrm{p}$ value $<0,05)$ sehingga dapat disimpulkan ada hubungan antara pola makan terhadap kejadian anemia dengan nilai $\mathrm{OR}=$ 0,407 .

\section{Pembahasan}

\section{Gambaran Karakteristik Responden Berdasarkan Usia}

Gambaran usia pada remaja putri di SMA Negeri 97 Jakarta pada tahun 2018 menunjukkan bahwa sebanyak 98 responden $(52,1 \%)$ merupakan remaja berusia 12-16 tahun (remaja awal) dan 90 responden $(47,9 \%)$ remaja berusia 17-21 (remaja akhir). Usia remaja merupakan masa peralihan dari anak menjadi dewasa yang dinyatakan dalam satuan tahun ditandai dengan sejumlah perubahan biologis, kognitif, dan emosional sehingga masa remaja adalah masa yang lebih banyak 
membutuhkan energi dan membutuhkan nutrisi dua kali lipat pada masa pertumbuhan. ${ }^{1}$

Remaja awal cenderung memperhatikan penampilan, sikapnya tidak menentu, dan berkelompok dengan teman sebaya. Remaja cenderung merasa bahwa wajah dan bentuk tubuh yang enak dipandang menjadi aset agar menjadi terkenal dan diterima oleh kelompoknya. ${ }^{15}$ Hasil penelitian ini sejalan dengan penelitian yang dilakukan di Kota Depok tentang faktor-faktor yang berhubungan dengan status anemia pada remaja putri bahwa proporsi remaja berusia 15-16 tahun sebanyak 248 Responden $(67 \%){ }^{16}$

Usia 15-16 tahun mempunyai body image sendiri sehingga remaja membatasi asupan nutrisinya. Hal tersebut membuat peneliti berasumsi kelompok usia remaja memiliki peluang mengalami kejadian anemia karena pertumbuhan dan perkembangan pada masa remaja menyebabkan perubahan gaya hidup dan perilaku konsumsi remaja. Aktivitas remaja yang semakin meningkat maka kebutuhan energi pun semakin banyak.

\section{Gambaran Status Gizi, Pola Makan, dan Kejadian Anemia Pada Remaja Putri di SMA Negeri 97 Jakarta}

Dari hasil penelitian menunjukkan bahwa sebanyak 62 responden (33\%) memiliki status gizi dengan IMT kurus, 106 responden $(56,4 \%)$ IMT normal, dan kategori IMT berlebih, yaitu sebanyak 20 responden $(10,6 \%)$. Status gizi merupakan kondisi tubuh responden yang dilihat dari makanan yang dikonsumsi dan penggunaan zat gizi. Nilai IMT merupakan salah satu alat ukur yang dapat digunakan untuk memantau status gizi. Status gizi berkaitan erat dengan konsumsi makanan sehari-hari, apabila makanan yang dikonsumsi baik, maka status gizi juga baik, sebaliknya apabila makanan yang dikonsumsi kurang nilai gizinya, maka akan menyebabkan kekurangan gizi dan anemia. $^{17}$

Remaja sebagian besar memiliki IMT normal karena remaja tinggal bersama orang tua sehingga pola dan jenis makanan terjamin dan diatur oleh orang tua. Pengetahuan remaja berperan terhadap sikap dan perilaku dalam pemilihan makanan. Usia remaja kemungkinan untuk mengetahui tentang anemia cukup banyak. Remaja yang memiliki pengetahuan yang baik cenderung bersikap baik. Remaja yang memiliki IMT kurus disebabkan oleh beberapa faktor seperti kebiasaan makan dan pemahaman gizi yang salah. Kesukaan dan pembatasan yang berlebihan terhadap makanan tertentu dapat menyebabkan tubuh gizi tidak terpenuhi. Status gizi kurang yang tidak diatasi dengan baik akan membahayakan remaja putri seperti terjadinya gangguan tumbuh kembang janin pada saat kehamilan.

Hasil penelitian yang dilakukan di Pondok Pesantren Putri Kecamatan Mranggan Kabupaten Demak Jawa Tengah bahwa kejadian anemia pada siswi pondok pesantren putri dengan kategori kurus sebesar 35\%. Sebagian besar responden memiliki asupan zat makanan dan jumlah kalori yang tidak adekuat sehingga menyebabkan gangguan status gizi. ${ }^{18}$ Peneliti berasumsi remaja dengan pola makan yang tidak benar, kebiasaan makan yang buruk, dan ketidaksukaan terhadap makanan tertentu mengakibatkan tubuh kekurangan zat gizi yang diperlukan oleh tubuh dan menjadi kurus.

Peneliti juga mendapatkan paling banyak responden berada pada kategori pola makan teratur sebanyak 89 responden $(47,3 \%)$ sedangkan responden dengan pola makan tidak teratur, yaitu sebanyak 99 responden $(52,7 \%)$. Pola makan merupakan cara seseorang dalam mempertahankan kesehatan, status nutrisi, mencegah dan membantu menyembuhkan penyakit dengan cara mengatur jumlah dan jenis makanan. Pola makan dapat dipengaruhi oleh faktor ekonomi, faktor agama, faktor lingkungan, faktor sosial budaya, dan faktor pendidikan. ${ }^{13}$ Remaja putri sebagian besar memiliki pola makan yang tidak teratur karena remaja putri lebih banyak menghabiskan waktu diluar rumah dan kebiasaan jajan serta ngemil sehingga remaja sudah merasa kenyang sebelum makan. Hasil studi menunjukkan bahwa remaja yang jarang sarapan pagi lebih banyak daripada remaja yang selalu sarapan pagi sebelum berangkat sekolah.

Sejalan dengan penelitian tentang hubungan pola makan dan pola menstruasi dengan kejadian anemia pada remaja putri di dapatkan hasil sebanyak 37 responden $(52.9 \%)$ berkategori pola makan tidak teratur dan 33 responden $(47.1 \%)$ pola makan teratur. ${ }^{10}$ Tingkat pengetahuan gizi seseorang akan mempengaruhi sikap dan perilaku seseorang dalam memilih jenis makanan yang dikonsumsi. Peneliti berasumsi aktivitas 
sekolah, berbagai kegiatan organisasi, dan ekstrakurikuler yang tinggi akan berdampak pada pola makan yang tidak teratur selain itu kebiasaan mengkonsumsi minuman yang menghambat absorbsi zat besi akan mempengaruhi kadar hemoglobin.

Responden sebanyak 100 remaja putri $(53,2 \%)$ mengalami anemia, sementara remaja putri yang tidak mengalami anemia ada 88 responden (46,8\%). Anemia merupakan masalah gizi pada remaja yang ditandai dengan penurunan kadar hemoglobin dalam darah kurang dari normal $(<12 \mathrm{gr} / \mathrm{dl})$ pada wanita. Anemia pada remaja putri mempengaruhi kondisi fisik dan apabila tidak ditangani dengan baik akan menimbulkan dampak yang berbahaya seperti gangguan pertumbuhan dan perkembangan, penurunan imunitas dan kemampuan fisik, perdarahan, dan kematian. ${ }^{19}$

Remaja putri sebagian besar berstatus anemia karena setiap bulannya mengalami menstruasi sehingga membutuhkan asupan zat besi yang banyak. Menstruasi yang tidak teratur dapat disebabkan oleh faktor stres, makanan yang dikonsumsi, aktifitas fisik, dan faktor genetik. Pola menstruasi yang tidak normal menyebabkan remaja putri mengalami perdarahan yang berlebih. ${ }^{20}$

Konsumsi zat besi yang kurang disebabkan beberapa faktor seperti kurangnya pengetahuan, ketersediaan pangan, dan kebiasaan makan yang salah. Remaja putri sebagian besar memiliki pengetahuan tentang anemia tetapi belum diterapkan dalam kehidupan sehari-hari seperti tidak sarapan sebelum berangkat sekolah dan sering mengganti makan pagi menjadi makan siang. Mayoritas remaja putri juga jarang mengkonsumsi makanan yang mengandung zat besi (heme iron) seperti daging, ikan, dan hati.

Penelitian tentang hubungan tingkat pengetahuan dan status gizi terhadap kejadian anemia remaja putri pada siswi kelas III di SMAN 1 Tinambung mendukung penelitian ini dengan datanya berupa remaja putri yang mengalami anemia sebanyak 74 responden $(67 \%) .{ }^{21}$ Begitu juga penelitian yang dilakukan pada tahun 2017 yaitu dari 50 responden 27 (54\%) mengalami anemia dan 23 responden $(46 \%)$ tidak mengalami anemia. ${ }^{22}$

\section{Analisis Hubungan Status Gizi dengan Kejadian Anemia pada Remaja Putri di SMA Negeri 97 Jakarta}

Hasil penelitian menunjukkan bahwa 42 responden $(67,7 \%)$ memiliki IMT kurus dan mengalami anemia sedangkan 20 responden $(32,3 \%)$ tidak mengalami anemia. Remaja dengan IMT Normal yang mengalami anemia sebanyak 46 responden $(43,4 \%)$ dan 60 responden $(56,6 \%)$ tidak mengalami anemia. Remaja dengan IMT Berlebih yang mengalami anemia sebanyak 12 responden $(60 \%)$ dan 8 responden $(40 \%)$ tidak mengalami anemia. Hasil analisa data dengan uji Pearson ChiSquare diperoleh nilai $\mathrm{p}=0,008$ ( $\mathrm{p}$ value $<0,05$ ) sehingga dapat disimpulkan ada hubungan antara status gizi dengan kejadian anemia

Status gizi merupakan gambaran besar akan zat gizi yang ada di dalam tubuh, salah satunya zat besi. Status gizi kurang merupakan salah satu faktor resiko terjadinya anemia. 17 Remaja putri yang memiliki status gizi normal dapat mengalami anemia apabila kebiasaan makan tidak seimbang. Remaja putri sering kali tidak memperhatikan konsumsi makanan sehingga sering makan makanan yang kurang sehat seperti gorengan dan jajanan cepat saji. Remaja putri sering melakukan diet yang tidak sehat dan tanpa pengawasan dokter atau ahli gizi dapat mengganggu pertumbuhan dan zat gizi yang diperlukan tubuh. Remaja putri juga sebagian besar sering minum teh atau kopi kurang dari satu jam setelah makan sehingga dapat mengganggu penyerapan zat besi yang dapat mempengaruhi kadar hemoglobin.

Oleh karena itu, sesuai dengan penelitian pada tahun 2013 yang menyatakan ada hubungan antara status gizi dengan kejadian anemia pada remaja putri. ${ }^{23}$ Penelitian pada remaja di Bolangitang Barat Kabupaten Bolaang Mongondow Utara menunjukkan hal yang sama yaitu ada hubungan antara indeks massa tubuh dengan kadar hemoglobin pada remaja.24 Anemia dipengaruhi secara langsung oleh konsumsi sehari-hari dan konsumsi makanan erat dengan status gizi, apabila makanan yang dikonsumsi baik, maka status gizi juga baik, sebaliknya apabila makanan yang dikonsumsi kurang nilai gizinya, maka akan menyebabkan kekurangan gizi dan anemia. Uraian diatas, tidak sejalan dengan penelitian pada remaja putri usia 12-14 tahun di SMP Negeri 9 Semarang yang hasilnya bahwa tidak ada hubungan yang bermakna antara 
status gizi dengan kejadian anemia pada remaja putri. Status gizi berdasarkan IMT lebih dipengaruhi oleh asupan zat gizi makro (karbohidrat, lemak, protein). ${ }^{25}$

Oleh sebab itu, peneliti berasumsi bahwa status gizi berhubungan dengan kejadian anemia karena makanan yang dikonsumsi sehari-hari berhubungan dengan status gizi. Makanan yang dikonsumsi memiliki kandungan zat gizi yang baik dalam jumlah yang cukup maka status gizi juga baik. Makanan yang dikonsumsi dalam jumlah yang sedikit dan kandungan zat gizi seperti seperti zat besi kurang, maka bisa menyebabkan terjadinya tubuh kekurangan bahan pembentuk sel darah merah dan memicu terjadinya anemia.

Analisa Hubungan Pola Makan dengan Kejadian Anemia pada Remaja Putri di SMA Negeri 97 Jakarta $(n=188)$

Hasil penelitian menunjukkan bahwa 37 responden $(41,6 \%)$ memiliki pola makan teratur dan berstatus anemia, 52 responden $(58,4 \%)$ tidak mengalami anemia. Remaja dengan pola makan tidak teratur yang mengalami anemia sebanyak 63 responden $(63,6 \%)$ dan 36 responden $(36,4 \%)$ tidak mengalami anemia. Dari hasil uji Continuity Correction diperoleh nilai $\mathrm{p}=0,004$ ( $\mathrm{p}$ value $<0,05)$ sehingga dapat disimpulkan ada hubungan antara pola makan terhadap kejadian anemia dengan nilai $\mathrm{OR}=0,407$

Pola makan dipengaruhi oleh faktor kebiasaan makan, yaitu cara seseorang memakan makanan dalam tiga kali sehari dengan frekuensi dan jenis makanan yang dimakan.13 Remaja putri dengan pola makan yang tidak teratur, memiliki pantangan makanan, sering jajan karena ikut ikutan teman, sering tidak sarapan, kebiasaan makan makanan cepat saji, dan junk food bisa menyebabkan terjadinya anemia. Remaja putri sebagian besar sering tidak sarapan pagi dirumah dan suka mengganti makan pagi menjadi makan siang karena terburu-buru berangkat sekolah dan merasa malas makan pagi.

Remaja putri juga kadang malas makan malam karena takut gemuk. Pola makan yang salah dan pengaruh pergaulan karena ingin memiliki tubuh yang langsing dan diet yang ketat bisa mengakibatkan berat badan turun dan tubuh kekurangan zat gizi yang dibutuhkan tubuh seperti zat besi. Keadaan tersebut, sejalan dengan hasil penelitian yang menyatakan bahwa ada hubungan pola makan dengan kejadian anemia pada remaja putri di MTs Ma'Arif Nyatnyono Kabupaten Semarang. ${ }^{10}$

Pola makan yang tidak baik menyebabkan anemia karena pola dan gaya hidup modern. Penelitian di daerah Riau tahun 2016 juga menegaskan bahwa ada hubungan yang bermakna antara pola makan dengan anemia. Pola makan rendah zat besi dan vitamin khususnya asam folat akan mengganggu proses metabolisme dan absorbsi zat gizi ke dalam tubuh. ${ }^{26}$

Namun, tidak sejalan dengan penelitian lain yang dilakukan pada tahun 2015 yang hasilnya bahwa tidak terdapat hubungan antara pola makan dengan kejadian anemia pada remaja putri.27 Asupan zat gizi yang tidak mencukupi kebutuhan gizi remaja menjadi salah satu penyebab rendahnya kadar hemoglobin dalam darah. Peneliti berasumsi bahwa pola makan tidak teratur beresiko mengalami anemia karena remaja putri sangat memperhatikan bentuk tubuh sehingga membatasi konsumsi makan dan kebiasaan makan yang buruk seperti tidak sarapan dan suka mengkonsumsi jajan.

\section{Kesimpulan}

Kesimpulan dari penelitian ini, sebagai

berikut Karakteristik usia responden menunjukan bahwa dari 188 responden berusia 12-16 tahun. Status gizi pada remaja putri menunjukan bahwa sebagian besar memiliki IMT normal. Pola makan remaja putri menunjukan bahwa sebagian besar memiliki pola makan tidak teratur. Kejadian anemia pada remaja putri menunjukan bahwa sebagian besar berstatus anemia. Dari hasil bivariate dapat disimpulkan bahwa ada hubungan antara status gizi dengan kejadian anemia dan ada hubungan antara pola makan dengan kejadian anemia.

\section{Saran}

Saran pada penelitian ini ditujukan terutama bagi remaja putri hendaknya lebih memperhatikan jenis makanan, frekuensi makan, dan jumlah makanan yang dimakan supaya dapat mencegah terjadinya anemia dan meminum tablet tambah darah apabila sudah merasakan tanda dan gejala anemia supaya tidak mengakibatkan dampak yang lebih serius. Pola makan yang sehat dari remaja tidak lepas berperan orang tua yang hendaknya mengawasi menyediakan menu makanan yang bergizi seimbang supaya gizi yang diperlukan oleh tubuh bisa terpenuhi seperti zat besi. Selain itu, 
pihak sekolah juga membantu perubahan perilaku hidup sehat dengan memberikan informasi lewat penyuluhan maupun pembuatan kantin sehat.

\section{Daftar Pustaka}

1. Proverawati. Anemia dan Anemia Kehamilan. Nuha Medika. Yogyakarta; 2011.

2. Adriani, M. \& Wirjatmadi, B. Peranan Gizi Dalam Siklus Kehidupan. Prenadamedia Group. Rawamangun; 2012.

3. Burner. Tips Anemia Tanda dan Gejala Kekurangan Zat Besi pada Remaja. 2012. Diakses tanggal 18 November 2016. http://bumbata.co .

4. World Health Organization/WHO. The global prevalence of anemia. Geneva; 2015.

5. Kementrian Kesehatan Republik Indonesia. Profil Kesehatan Indonesia. Kemenkes RI. Jakarta; 2014.

6. Kusharisupeni, A. Vegetarian Gaya Hidup Sehat Masa Kini. Andi Offset. Yogyakarta; 2010.

7. Badan Penelitian dan Pengembangan Kesehatan Kementrian Kesehatan RI. Riset Kesehatan Dasar (Riskesdas). Balitbangkes. Jakarta; 2013.

8. Briawan, D. Anemia Masalah Gizi pada Remaja Wanita. EGC. Jakarta; 2013.

9. Sianipar, O., dkk. Prevalensi Gangguan Menstruasi dan Faktor-Faktor yang Berhubungan pada Siswi SMU di Kecamatan Pulo Gadung Jakarta Timur. Majalah Kedokteran Indonesia. 2009; 59(7): 308-313.

10. Utami, BN., Surjani, \& Mardiyaningsih, E. Hubungan Pola makan dan Pola Menstruasi dengan Kejadian Anemia Remaja Putri. Jurnal Keperawatan Soedirman. 2015; 10(2): 67-75.

11. Masthalina, dkk. Pola Konsumsi (Faktor Inhibitor dan Enhancer Fe) terhadap Status Anemia Remaja Putri. Jurnal Kesehatan Masyarakat. 2015; 11(1): 80-86.

12. Arumsari, E. Faktor Resiko Anemia pada Remaja Putri Peserta Program Pencegahan dan Penanggulangan Anemia Gizi Besi (PPAGB) di kota Bekasi. Skripsi IPB. Bogor; 2008.

13. Sulistyoningsih, H. Gizi untuk Kesehatan Ibu dan Anak. Graha Ilmu. Yogyakarta; 2011.

14. Roizen, dkk. Menjadi Remaja Sehat: Panduan Anak Muda dan Orang Tua untuk Kesehatan Usia Puber. Mizan Media Utama (MMU). Jakarta; 2012.

15. Adriani, M. \& Wirjatmadi, B. Pengantar Gizi Masyarakat. Kencana. Rawamangun; 2012.

16. Siahaan, NR. Faktor-Faktor yang Berhubungan dengan Status Anemia pada Remaja Putri di Wilayah Kota Depok Tahun 2011. Skripsi FKM UI. Depok; 2011.

17. Supriasa, I. D. N., Bakri, B., \& Fajar, I. Penilaian Status Gizi. EGC. Jakarta; 2014.
18. Astuti, R. \& Rosidi, A. Kadar Hemoglobin pada Siswi Pondok Pesantren Putri Kecamatan Mranggen Kabupaten Demak Jawa Tengah. Prosiding Seminar Nasional Hasil-hasil Penelitian dan Pengadian. Unimus. Semarang; 2014.

19. Manuaba, I. Penyakit Kandungan dan Keluarga Berencana untuk Pendidikan Bidan. EGC. Jakarta; 2010.

20. Wahyuningsih \& Astuti. Hubungan Kadar Hemoglobin dengan Keteraturan Siklus Menstruasi pada Mahasiswi Prodi DIII Kebidanan Tingkat III STIKES Muhamadoiyah Klaten. Jurnal Involusi Kebidanan. 2011; 2(3): 34-35.

21. Hapzah \& Yulita, Ramlah 2012. Hubungan Tingkat Pengetahuan dan Status Gizi terhadap Kejadian Anemia pada Remaja Putri pada Siswi kelas III SMAN 1 Tinambung Kabupaten Polewati Mandar. Media Gizi Pangan. Kesehatan Masyarakat STIKES Bima Bangsa Majane. 2012; Vol. XIII. Edisi 1.

22. Basith, A., Agustina, R \& Diani, N. FaktorFaktor Yang Berhubungan Dengan Kejadian Anemia Pada Remaja Putri. Dunia Keperawatan. 2017; 5(1): 1-10.

23. Wibowo, C. D. T., Notoatmojo, H., \& Rohmani, A. Hubungan Antara Status Gizi dengan Anemia pada Remaja Putri Di Sekolah Menengah Pertama Muhammadiyah Semarang. Jurnal Kedokteran Muhammadiyah. 2013; 1(2): 1-5.

24. Sukarno, K. J.., Marunduh, S. R., \& Pangemanan, D. H. C. Hubungan Indeks Massa Tubuh dengan Kadar Hemoglobin pada Remaja di Kecamatan Bolangitang Barat Kabupaten Bolaang Mongodow Utara. Jurnal Kedokteran Klinik. 2016; 1(1): 1-7.

25. Indartanti, D. \& Kartini, A. Hubungan Status Gizi dengan Kejadian Anemia pada Remaja Putri. Journal Of Nutrition College. 2014; 3(2): 33-39.

26. Fitri, L. Hubungan Pola Makan dengan Anemia pada Pekerja Wanita Di PT. Indah Kiat Pulp And Paper (IKPP) Tbk. Perawang Journal Endurance. 2016; 1(3): 152-157.

27. Suryani, D., Hafiani, R., \& Junita, R. Analisis Pola Makan dan Anemia Gizi Besi pada Remaja Putri Kota Bengkulu. Jurnal Kesehatan Masyarakat Andalas. 2015: 10 (1): 11-18. 